The Difference Language Makes

The LifeHistory of Nahuatl in Two Mexican Families.

Pharao Hansen, Magnus

Published in:

Journal of Linguistic Anthropology

DOI:

10.1111/jola.12115

Publication date:

2016

Citation for published version (APA):

Pharao Hansen, M. (2016). The Difference Language Makes: The LifeHistory of Nahuatl in Two Mexican

Families. Journal of Linguistic Anthropology, 26(1), 81-97. https://doi.org/10.1111/jola.12115 
- Magnus Pharao Hansen

Department of Anthropology

Brown University

Center for US-Mexican Studies UCSD

magnuspharao@gmail.com

\section{The Difference Language Makes: The Life-History of Nahuatl in Two Mexican Families}

In this article, I describe two families from two different Mexican communities where the Nahuatl language is spoken. In both families the parental generation speaks Nahuatl as a first language, but the way that the adult children use and relate to the language varies widely between the families and between the individual siblings within a family. Some master the language and have made the language an important source of identity and livelihood, whereas others have all but abandoned it. I describe how this variation in linguistic outcomes is related to the children's life histories, including the influence of significant life events and educational experience, which are in turn tied to political changes in Mexican society. I show how the Nahuatl language has been a source of different options and obstacles in their lives. I propose that a life-history perspective on language transmission anchored in a phenomenological semiotics will enhance our understanding of the relation between language ideology and agency. [Nahuatl, Mexico, phenomenology, semiotics, language socialization]

- One day in the spring of 2013, thirty-year-old Ana Espinoza decided to no longer to dye her naturally black hair blond. That same week she had been to a meeting with a lady from the CDI, The National Commission for the Development of Indigenous Peoples, who had told her that she didn't qualify to receive assistance for her small-scale business project. The lady had told Ana that if she had lived in her pueblo of origin instead of in the city of Cuernavaca, and if she had learned to speak the Nahuatl language as her parents did, then she would have qualified for economic support.

- Another day that same spring, seventeen-year-old Feliciana Aguilar decided not to continue on to high school after finishing secondary school in July. Whereas her primary school teachers had all spoken and taught in Nahuatl, her mother tongue, in secondary school all classes were taught in Spanish and it was hard to keep up. She had had a hard time making friends, and that week she had scored lowest in her class on a test of Spanish orthography, and received several snide comments from her classmates. understanding our life choices is to see them as embedded within

Journal of Linguistic Anthropology, Vol. 26, Issue 1, pp. 81-97, ISSN 1055-1360, EISSN 1548-1395. Copyright (C) 2016 American Anthropological Association. DOI: 10.1111/jola.12115. 
genealogies of experience shaped by social contexts and interactions, which are in turn framed by historical events like changing education policies, financial crises, and presidential elections. No one's choices are of course fully determined by these events or by our interactions with others-but they are undeniably significantly influenced by them, and furthermore severely constrained by the limited number of options our life situations afford us. Although Ana and Feliciana grew up hundreds of kilometers apart, in two different Mexican states, their personal relation to the Mexican indigenous language Nahuatl played a crucial role in motivating their choices, as well as in determining their options. For Ana, the fact that she didn't speak Nahuatl, a language spoken by her parents and several of her siblings, meant that she did not have access to certain types of government aid available to her family members. For Feliciana her choice was motivated by the difficulties that she faced as a predominant speaker of Nahuatl within a Spanish-dominated education system. In both cases the constraints imposed on their decisions resulted from aspects of the political strategies used by different branches of Mexican government that regulate how it relates to its indigenous population.

\section{Life and the Meaning of Language}

Departing from the life histories of Ana and Feliciana and some of their family members, in this article I explore how the linguistic choices of every individual are made in the context of a lived life. I argue that by focusing on individuals, their immediate social relations, and how their life choices are embedded within idiosyncratic genealogies of experience, interactions, options and constraints, we may become able to see how the effects of linguistic discourse, language policy and cultural politics make their way into individual lives. From this perspective we can see new aspects of how individual agency, the subjective dynamics of experience, interpretation, and choice, plays into the outcomes of glotto-political processes.

A series of theorists in linguistic anthropology have argued that the semiotic approach, by now traditional in linguistic anthropology, including our attention to metapragmatics and interdiscursivity, could well be combined with a phenomenological approach to meaning and experience. Scholars who have worked in this vein include Hanks $(1990,1992,1996)$ whose approach to deixis and indexicality is grounded in Merleau-Ponty's sensory and embodied phenomenology. In a series of recent articles Duranti $(2006,2009,2010,2011)$ and Ochs (2012) have proposed that a Husserlian perspective on phenomenology, including the relevance of intentional stances, would be a welcome addition to the theoretical apparatus of linguistic anthropology. And most recently Kockelman (2013) has proposed a synthesis of Peircean semiotics with a Heideggerian existential phenomenology. Taken together, these theorists suggest that by understanding how signs become meaningful, not only through their grounding in infinite chains of indexical orders (Silverstein 2003), but also ultimately through their grounding in lived reality experienced as a sign (i.e., a phenomenon in the Husserlian sense), we may come yet closer to understand the relation between language, experience and social life.

My own approach in this article, builds on the insights of Wittgenstein, which see meaning as grounded in fields of practice, what he calls "forms of life." One aphorism by Wittgenstein, published posthumously in Culture and Value, states that "the words you utter or what you think as you utter them, are not what matters, so much as the difference they make at various points in your life (Wittgenstein1984:85e). This echoes Kockelman's (2013) suggestion following Heidegger, that it is the "existential affordances" of a sign that produce its ultimate interpretant.

In this article I explore how the Nahuatl language have become a significant element in the ways that the members of two Mexican families, have come to interpret their own lives as signs. I show how the affordances offered by the Nahuatl language to a given individual, emerge in the interplay between the concrete social context, as well as on the genealogy of experiences through which the context is interpreted. 


\section{Language in the Family}

In her seminal article "What No Bedtime Story Means," Brice-Heath (1982) showed how differences in linguistic experience, particularly early literacy experience, influenced the linguistic competencies, communicative repertoires and educational trajectories of children growing up in three different American communities. Similarly, the communities analyzed here are united by the fact that they speak a common language and exist within a single sociopolitical system, but represent very different communicative cultures and language ecologies.

Subsequent studies of language socialization have shown the important role of household and kinship-based interactions in influencing the linguistic outcomes for bilingual children (e.g., Pérez Báez 2012, 2014; Zentella 1997, 2005). These studies have shown that in spite of an explicit willingness of parents to preserve an endangered language, the process may still fail if it is not supported by actual linguistic practices (Rindstedt and Aronsson 2002,), or if it is embedded in a network of negatively valued social practices (Kulick 1995). But family interactions alone do not determine linguistic outcomes; peer interactions, life events, changing educational policies and discourses, all play into the process and produce varying linguistic repertoires, degrees of bilingualism and language attitudes within a single household, or from a single set of language socialization practices. In her masterful study of the linguistic practices and choices of bilingual Puerto Rican youths in Spanish Harlem, Zentella (1997) demonstrated how social processes in family and peer contexts may interact to produce lived experiences that are incommensurable with the often simplistic understandings of language implicit in the workings of the English dominant education system. She showed how this mismatch between home and school environments, eventually motivated some Puerto Rican families to shift focus to English, gradually phasing out the full bilingualism of the earlier generations and moving toward English monolingualism. Zentella provides an important insight in showing how dominant metalinguistic discourses and their enforcement through the educational and even medical systems affect human lives. This does not happen primarily through changes in the explicit ideologies and values espoused by speakers, but when dominant discourses translate into concrete obstacles or aids in their lives. This suggests to me that language ideologies that seek to regiment language use either through enforcing the "monoglot standard ideology" (Silverstein 1996) or through insisting on the inherent value of linguistic diversity, are not the only drivers of linguistic choices. I propose that metalinguistic ideologies to be effective need to take hold in the ground of lived experience, and that the effect they have is mediated by this existential anchoring.

In this essay, I portray the families of Ana and Feliciana. The Espinoza and Aguilar families live in two different regions of Mexico with very different sociolinguistic situations. ${ }^{1}$ The cultural and economic policies of the Mexican state have affected the two families in different ways, and have imposed different options and constraints on various family members. Furthermore, the average age of the Espinoza family is slightly higher than that of the Aguilar family, meaning that its members came of age and made many of their life choices in a slightly different period of Mexican history. This is particularly significant because of the changes in cultural politics that Mexican government has effectuated in the last 10 years. The family portraits thus give us an idea of how these political changes are affecting the lives of indigenous Mexicans.

\section{Nahuatl Sociolinguistics}

Nahuatl is Mexico's most populous indigenous language with more than a million speakers. It also has the largest geographical spread, and is spoken in dispersed regions, enclaves and towns from Durango to Tabasco, with the bulk of the speakers located in the states of Puebla, Veracruz, Hidalgo, San Luis Potosí, and Guerrero 
(INEGI 2005). The label Nahuatl also covers a wide continuum of linguistic varieties, some of which are only partially mutually intelligible - and many of which use different local names. The Mexican government describes the language as being in a process of "slow extinction," with the number of speakers growing at a slower rate than the population (CDI 2012). The sociolinguistic situation of the Nahuatl language has been amply studied, but with a somewhat narrow topical focus on the issues of language contact between Spanish and Nahuatl, and on the metadiscursive ideologies that are implicated in the process of language shift. Comparably little attention has been given to the study of language acquisition and socialization. The research has also had a fairly narrow regional focus, with the most influential studies being carried out in the state of Tlaxcala, in the Malinche/Malintzi region, where the Nahuatl language is in an advanced stage of decline. Only a few studies have taken place outside of this region (among them prominently Flores Farfán [1999, 2011]). These studies however, also focus on regions where the process of language shift is advanced. The regions where Nahuatl is vigorous, such as La Huasteca, Central Guerrero, the Sierra Norte de Puebla, and the Sierra Zongolica have not been the focus of comparable sociolinguistic attention.

The most seminal work on Nahuatl sociolinguistics is doubtless Jane and Kenneth Hill's Speaking Mexicano (1986), which describes how the speakers of Mexicano (the local name of the Nahuatl language in Tlaxcala), strove to make sense of their own bilingualism as they operated with contradicting language ideologies and practices. While the Mexicanos explicitly valued linguistic purity, and desired the linguistic codes of Spanish and Mexicano to be kept separate, in practice they also used language mixture to perform social functions, such as signaling alignment with the political power symbolized by Spanish. The study demonstrated the complex social dynamics of "prestige," showing how the relative prestige associated with varieties may vary between social contexts. The Hills explicitly noted the sociolinguistic disconnect between the "public" and the "private" domains of usage, and how the value of Nahuatl for its speakers was largely defined by its role as a "code of solidarity" and the semiotic vehicle for intimate social relations. In this way the pointed to the significance of the family context for understanding aspects of how Nahuatl becomes meaningful to its speakers.

In a series of subsequent studies of language shift from Mexicano/Nahuatl to Spanish in Tlaxcala, Messing described three competing metadiscourses that ascribed either a positive or negative value to the indexical network that surrounds the Nahuatl language, culture, and identity (Messing 2002, 2007a, 2007b). Messing labeled a Nahuatl-denigrating discourse "menosprecio," and a Nahuatl positive discourse, "pro-indigena," A third metadiscourse, "salir adelante," prioritized socioeconomic advancement. She argued that since Mexicano youths must navigate between these discourses individually as part of a process of situating themselves within modernity, these discourses are particularly important for determining the future of the Nahuatl language and Mexico's other indigenous languages. In another work Messing (2007b) examined the ideologies that tie the use of Nahuatl to the private sphere in Tlaxcala, making it a vehicle of intimacy, trust and kinship relations. Messing and Rockwell (2006) also attended to the role of the Mexican education system as a site of transmission of language ideologies about Nahuatl through participant observation in schools that had begun implementing Nahuatl revival programs. They found that the introduction of bilingual schools in Tlaxcala, held the promise of opening up spaces for the renegotiation of the relative value of Nahuatl and Spanish. Similarly, Messing (2007) signaled the relevance of studying language transmission within a family context, and the need to understand how similar metadiscursive regimes operate in other ethnographic contexts.

This previous research has set the stage for a focused attention to the interplay of metalinguistic discourses and language practices, and to the ways that these are mediated by differences between social contexts - such as the public contexts of governance and education, or the private contexts of family and peer relations. In this 
study, tie Zentella's insights about the importance of the school-family interface in creating the sociolinguistic landscape that speakers of minority languages navigate to Messing's work on the metalinguistic discourses about the value of Nahuatl. In doing this, I find that metalinguistic discourses about indigenous languages, whether they value the language positively or negatively, are refracted through the texture of subjective life experiences, local forms of life, and the life projects they afford. Like Messing, I consider the discourse of "salir adelante" that encourages individuals to "pull themselves up by their bootstraps" to be of immense importance in understanding how Nahua people react in relation to their language. But I suggest that for idiosyncratic reasons having to do with the ways that our lives unfold as a semiotic process in which we make sense of the various external circumstances that constrain us, some Nahua youths end up experience their language as a vehicle for their life projects, and others as an obstacle.

\section{Toward a Multicultural Mexico}

Scholarly assessments of Mexican indigenous policies in the twentieth century have been highly critical, viewing Mexican cultural policies to have been aimed squarely at assimilating indigenous peoples into the national mainstream through aggressive programs encouraging castellanización [hispanization] and mestizaje (mixing) (Bonfil Batalla 1981; Friedlander 1976; Messing 2007a). But the final decade of the twentieth century saw a discursive and political change in the way that Latin American states related to their indigenous minorities. From discourses about Indians revolving around the theme of an "Indian problem," Latin American states have increasingly adopted rights- based discourses of indigeneity as well as ideologies of multiculturalism. In 2003 the government of Vicente Fox passed the 2003 Law of Linguistic Rights which institutionalized the country's indigenous languages as "national languages" technically equivalent in status to Spanish "within their respective ambits." This law gave indigenous people the right to receive obligatory education and other government services in their own languages as well as Spanish. The law also eliminated the National Indigenist Institute (INI), which had previously been in charge of all indigenous issues and operated under a paternalist and neocolonialist indigenist framework which had been severely criticized by anthropologists and indigenous activists (e.g., Friedlander 1975, 1981; Brice-Heath 1972; Schmelkes 2000). It was replaced with two new institutions: Comisión Nacional para el Desarrollo de los Pueblos Indigenas [National Commission for the Development of Indigenous Peoples] $(\mathrm{CDI})$, the charter of which is to promote social and economic development in indigenous communities, and the Instituto Nacional de Lenguas Indigenas [National Institute of Indigenous Languages ] (INALI), which was charged with revitalizing and strengthening the country's indigenous languages. The law also established an educational regime based on the ideology of Intercultural Bilingual Education (EIB), according to which the minority and majority languages engage on what is supposed to be an equal footing, instead of the clearly hierarchical conceptualization of majority and minority languages implicit in the previous education regime which had castellanización as its explicit goal.

Since 2003 the national budget allocated to "attention to indigenous peoples" has increased by 390\% (CDI [Comisión Nacional Para el Desarrollo de los Pueblos Indígenas], 2012), with most of the funding being invested in programs of socioeconomic development of indigenous communities, but also in programs aimed at "stabilizing and strengthening Mexico's indigenous languages" (INALI's mission statement). In the area of education, the establishment of indigenous language education as a right rather than as an optional pedagogical strategy in the teaching of Spanish, caused renewed efforts to provide bilingual education to indigenous students. The most ambitious project in this regard has been the establishment of 10 Intercultural Universities in rural areas with indigenous populations. These new universities are aimed at providing postsecondary education to indigenous youths 
within a framework of interculturality. Their objective is to educate indigenous people who can participate in the development of their local communities in a way that understands, recognizes and respects local cultural contexts (Schmelkes 2009).

In the life histories I present below, I demonstrate aspects of the significance of these political developments for speakers of indigenous languages in Mexico. Specifically, the increased institutionalization of indigenous languages provides new options for life projects for youths who speak them. But it also creates new tensions between Nahua youths whose access to the linguistic capital suddenly afforded by the Nahuatl language is differentiated by life circumstances outside of their own control.

\section{Two Towns: Hueyapan, Morelos and Tlaquilpa, Veracruz}

The Espinozas live in Hueyapan, Morelos, a community famous among anthropologists as the setting of Friedlander's influential ethnography of race and identity, Being Indian in Hueyapan. As described by Friedlander, the history of Hueyapan has been one of sociopolitical marginalization, as well as a history of being actively forced into an identity category as "Indians." While at the turn of the twentieth century Nahuatl was spoken throughout the state of Morelos, the language disappeared very rapidly in the state following the Mexican revolution and Nahuatl- speaking communities became increasingly isolated, conducting all intercommunity relations in Spanish. Today few youths speak the language, some having merely passive competence, and most having none at all.

Throughout the twentieth century, Hueyapan has furthermore depended politically on the municipal cabecera [municipal seat] of Tetela del Volcán, a situation that has contributed to keeping Hueyapeños in the role of the underdeveloped, undereducated Indians to Tetela's cultural elite. ${ }^{2}$ Further cementing this image has been the fact that Hueyapan's economy during the twentieth century was largely fueled by the illegal production of marijuana - the only cash crop available in the mountainous region until the recent adoption of fruticulture. The importance of this illegal economy has meant that Hueyapan has been frequently visited by government troops, and that for much of the twentieth century it maintained a culture of lawlessness, with stark economic inequality, violent family feuds, mob lynchings of outside delinquents, and an intense social pressure on everyone to mind their own business. Recent decades have seen a complete change of this situation as foreign remittances and fruit production have taken the place of marijuana production as the main sources of income. This has coincided with a rapidly improving infrastructure connecting Hueyapan to local communities, and with a political resurgence, as two Hueyapeños have managed to successfully challenge the political hegemony of Tetela by becoming municipal presidents in 2006 and 2012. The same period has seen a change in local identity, which is increasingly coming to be seen in a positive light, resulting in an increased focus on traditional crafts production, and in reviving the local language. Currently, Nahuatl is only used in one of Hueyapan's four kindergartens, where it is taught as a second language, and in one of the five primary schools. Several projects aimed at teaching Nahuatl to youths are under way, driven by support from state and municipal administration.

The Aguilar family lives in the community of Bella Vista, in the municipality of Tlaquilpa located in the mountainous Zongolica region of central Veracruz. Extending south from the city of Orizaba, Zongolica is a vast rocky and cold region bordering the states of Puebla and Oaxaca. The main resource in the Sierra de Zongolica is the forest, and traditionally the people there have subsisted by producing and selling charcoal and lumber, and by growing small plots of corn and vegetables on the rocky slopes. The lack of natural resources makes the Zongolica region one of the poorest in Mexico, the municipality of Tehuipango occupying for several years in a row the place as "Mexico's poorest municipality." Outward migration is rampant, both to the United States and to Mexico's richer northern 
regions. Infrastructure remains rudimentary: While they have electricity, much of the region does not have cell phone and Internet coverage, and public transportation is costly and time-consuming (Tlaquilpa is two hours from the city of Orizaba by bus and a ticket is 40 pesos, more than half the daily minimum wage).

The Nahuatl language is spoken by some 120,000 people in the region, which represents the vast majority of the inhabitants. In some municipalities, there is a high percentage of Nahuatl monolinguals: as many as $15 \%$ in the municipalities of Tehuipango and Mixtla de Altamirano. Intercommunity communication is often carried out in Nahuatl, and while the varieties of each local community are distinct, they are also mutually intelligible. Most Nahua speakers are able to both understand other local dialects and to identify them by community. For example, every community has its specific set of greetings in Nahuatl, which are known and understood by people from the other communities. The language is spoken by most children and youths, and is widely used not only in the private sphere, but also in public contexts, including the political sphere (at the municipal offices and at political rallies) as well as on the street. Spanish tends to be used in communication with outsiders, such as political officials, doctors, teachers many of whom commute into the region from the surrounding area.

Primary education has been carried out bilingually for a long time, although recent efforts to professionalize the teaching staff has led to an influx of non-Nahuatlspeaking teachers from other regions. As a legacy of the earlier strategy of "subtractive bilingualism" with the object of making all students fluent in Spanish by the end of primary school, there is no institutionalized indigenous language secondary education in the Nahuatl-speaking regions, or even in most of Mexico. Furthermore, in secondary school, most teachers come from outside the region and do not speak indigenous languages. In 2006 a branch of the Intercultural University of Veracruz was opened in the region offering a BA degree in intercultural development. The school competes with the only other institution of postsecondary learning, the Technological Institute of Zongolica, which offers degrees in engineering, information technology and forestry. Initially having a student population of 200, enrollment has now fallen to around 80 students, prompting the university to undertake a more aggressive recruitment in the area, and to streamline its organization and educational offerings. The intercultural university has provided significant new options for local youths, specifically to several some members of the Aguilar family, but as we will see below, the ability to access to these options is mediated by several other factors.

\section{Two Families: The Espinozas and the Aguilars}

I met the Espinoza family during my first period of linguistic fieldwork in Mexico in 2003, and over the years I have come to know them very well. I have stayed in their house for more than two years altogether and maintained close contacts when I was away. In contrast, I only met the Aguilar family in the fall of 2012 when I started doing ethnographic fieldwork at the Intercultural University in Tequila, Zongolica, where two family members are students and another is a member of the faculty. I have stayed with them for about a month since then, conducting life history interviews and participating in family life as much as I could while commuting to the Intercultural University. This difference in the length and intensity of engagement obviously means that my account of the Espinoza family has more historical depth, covering a period from the mid-seventies to the present, whereas my account of the Aguilar family focus on events taking place in the past five to six years.

\section{The Espinoza Family}

When I first met the Espinozas they were a group of four siblings living with their mother Maria (51) in a large adobe house. Maria had become the owner of the house 
when her husband died and her mother-in-law went to live with her daughters. The four children who lived with her were Clara (30), Renato (27), Ronaldo (24), and Celia (17). The remaining three siblings lived elsewhere: Ana (23) in Cuernavaca where she worked as a maid and caretaker of a mansion, Adán (21) in New York where he worked in a Manhattan restaurant, and the eldest, Rodrigo (33), who worked as a cabdriver in Xalapa, Veracruz. I met the family through Clara because of our shared interest in studying Nahuatl language. Most of my detailed knowledge of the family and its history comes through her perspective, although I have of course talked to all of the other family members to understand theirs.

María and her husband León met when they were both in their teens. She was the daughter of a family from Hueyapan's central San Miguél Barrio, the home of the local class of cultural progressives: teachers, the few intellectuals, and local authorities. From childhood, her mother taught her to cook, to spin woolen thread on the spindle whorl, and to weave on the backstrap loom-all the skills of a traditional Hueyapan woman. Her parents spoke Nahuatl as a first language, but limited their communication with their children to Spanish following the advice of the schoolteachers who argued that that was the best way of making sure that they would do well in school. Nonetheless, Maria and her siblings quickly picked up Nahuatl in the streets playing with their friends - most of them becoming fully bilingual. León, on the other hand, grew up in the Barrio San Andrés farther up the hill. San Andrés was the home of a group of pioneering farmers who had been the first to move up and cultivate the slopes of Xonakayohkān [Place full of onions] as the barrio is called in Nahuatl. The campesinos [peasants] of San Andrés planted corn and beans, and raised cattle in the wooded hillsides, but a significant number of them also produced marijuana. León's father was one of these producers, and that was how he financed the construction of the two-story adobe house. Known as a fierce and violent man who was generous to his friends and ruthless to his enemies, he was stabbed to death in a fight when León was a still young boy. León then grew up alone with his mother, learning to take care of the land, and taking over his father's marijuana business. While bilingual, his first language was Nahuatl as his father had spoken little Spanish and his mother none at all. This was not uncommon in the outlying barrios of Hueyapan at that time in the 1960s. He met María and the two fell in love, and without asking her parents for permission he brought her to live with him in San Andrés in the act commonly called "robarse una novia" [stealing a bride]. María, still in her teens, came to live with her husband and his mother, in the subordinate role that traditionally befitted the in-married wife in much of rural Mexican culture. Rodrigo and Clara were born in the early 1970s while their parents were still in their early twenties.

In the late 1970s, and early 1980s, Hueyapan changed. As a result of the "War on Drugs" declared by the United States, the Mexican government began to undertake frequent military raids to find and confiscate marijuana crops and drag the campesinos who produced it off to jail. Among Clara's earliest memories is such a raid. She remembers soldiers barging in the door and rummaging through her parent's belongings, finding and confiscating a wad of money that her father had received that day for the sale of a few pigs. Her father ran up the stairs and jumped off the balcony, kicking over a soldier and escaping into the deep ravine on the other side of the road. The soldiers, not content with León's escape, came back a few weeks later to arrest his wife María as a hostage, thus forcing León to turn himself in. She was carried off to the women's correctional facility in Mexico City, with her threemonths-old baby Renato wrapped in her shawl. Rodrigo and Clara, five and three years old, respectively, were raised during the next few years by their grandmother, until their father, tired of being on the run, finally turned himself over to the police, and María was released.

Living now with their grandmother, Rodrigo and Clara grew up in a Nahuatl monolingual home, using Spanish only in school - and there, only with those of their friends who didn't speak the language. In the Nahuatl language their grandmother 
taught them the rules of proper living, how to dress, how to speak and act with respect, and how to venerate the saints. When Clara remembers her grandmother's words they always resound in Nahuatl: From the admonishment to always sit as a proper girl with her legs closed ("ammo xitlakahkalo!"), to the correct and respectful way to talk about the sun and the moon (tonnaltzintle and métztzintle, respectively, always with the honorific suffix -tzin-), and to not point one's finger at the rainbow lest it should swell up ("ammo xikmapilwihtimimi in kosamalotl porkeh timahpilotztiyas"). Even when their mother came back from prison, the two remained close to their grandmother. As adolescents, both switched to mostly speaking Spanish, but the sound of Nahuatl stayed with them in the memory of their grandmother's words, and more than any of their siblings they learned to both understand and pronounce it. Renato, now a toddler, grew up listening to Nahuatl spoken between grandmother and his elder siblings and his mother, and though he never spoke it much, he was fully able to understand it.

León came back from prison in 1985, and the next siblings were born in rapid succession. Ana and Adán grew up in a household that was now increasingly Spanish-speaking, and consequently they only picked up set phrases and the most common vocabulary in Nahuatl. León, still working to sustain his growing family by any means necessary, quickly ran into trouble as new families had now taken over the marijuana trade in an increasingly violent Hueyapan. In the 1990s a feud started between María's family and a powerful marihuanero [marihuana farmer] family, and León stood on the side of his brothers-in-law. He barely survived several assassination attempts, and the family lived in constant fear, as several of their uncles and cousins were gunned down in shootouts.

During this period Clara and Rodrigo decided to abandon the Catholic religion. One of their aunts had converted to the newly arrived religion of Jehovah's Witnesses some years earlier, and through her they had become acquainted with the religion and its beliefs and practices. Their mother María had taken an interest in the religion and brought them to some meetings, but she soon abandoned it. Clara and Rodrigo nonetheless found something they had been looking for and which provided an escape from the violence and fear that characterized their home. The pacifist Witnesses repudiate arms, violence, and drugs, and their practices and doctrines focus on using critical reasoning and active evangelization as the path to God, in contrast to what they view as the more mysticist and exuberant Catholic practices. Clara had been a baptized Witness for several years, defiantly opposed to her father's irresponsible lifestyle, when he was killed in an ambush by a group of gunmen from the opposing family. The youngest brother Adán, now 16, was a young hothead with a knack for getting into trouble, and the family convinced him to go north to the United States in hopes (which was realized) that this would keep him safe. Ana had been hired as a maid and caretaker by a rich family with a weekend home in Cuernavaca. Clara dedicated herself to her religion, and particularly enjoyed the evangelization aspect of its practice. This required her to visit people in Hueyapan, many of them old and Nahuatl-speaking, talking about her religious beliefs and teaching them to read the scriptures. This caused her to take up the Nahuatl language again, relearning much of what she had by then forgotten. The Hueyapan Witnesses began to practice Nahuatl as the main language of their religious meetings, making their Nahuatl skill even more meaningful and valuable to Clara and Rodrigo (see Pharao Hansen 2010). As an Elder of the faith, Rodrigo now traveled to other states to give speeches and religious instruction in Nahuatl communities. Clara for a while traveled as a missionary to a Nahuatl-speaking community in Hidalgo, improving her fluency, which had suffered from many years of speaking mostly Spanish.

This was what the family was like when I met them in 2003, when Clara brought me to visit many of the old people that she was teaching about the doctrines of the Witnesses: they became my first teachers in Nahuatl. She experienced significant success as an evangelizer, which she ascribes to her use of Nahuatl. Eventually Rodrigo returned home to work as a carpenter and an Elder among the Witnesses, 
Renato left to join his brother in the United States. After 15 years in the United States, Adán speaks English fluently, though Renato is still learning it.

When I arrived in Hueyapan in the fall of 2013, there were many new developments related to the Nahuatl language. A new, leftist governor had been elected who had made promises of helping indigenous communities, by giving them status as independent municipalities, and by implementing programs of Nahuatl revival across the state. At the same time, increasing federal funds were allocated to projects of social development in indigenous communities, many of them in the form of start-up funding for small crafts businesses and cooperatives. It was at this moment that Ana told me about the experiences trying to access those funds mentioned in the prologue. Her project of producing preserved fruits and jams had been rejected by the CDI on the grounds that she did not live in an indigenous community, but in the city of Cuernavaca where she had worked since she was 18, and that she did not speak an indigenous language. She was clearly upset at this rejection, which she found unfair, and basically a declaration that she was "not indigenous enough" to deserve help. That spring she stopped dying her hair blond, and started wearing "indigenous style" embroidered cotton blouses instead of the American clothes sent to her from her brothers in the United States. She also asked me if she could have copies of my Nahuatl materials in order to start learning the language on her own. I asked her if this change of attitude had anything to do with the rejection by the CDI, but she said it didn't; it was just because her work had wound down and her children were a little older now, which gave her time enough to take up aspects of her family heritage that she felt she lacked.

\section{The Aguilar Family}

I first met the Aguilar family in the fall of 2013 when I was doing fieldwork on the use of Nahuatl at the Intercultural University of Veracruz in Tequila Zongolica. I first met Zacarias (24), who was one of the only faculty members at the University who was a native Nahuatl speaker. I asked him if he could help me find a family where I could stay in his community; he agreed and, to my surprise, brought me to stay with his own family.

The family lives in two large plank houses on the side of a ridge overlooking a large valley with the town center of Tlaquilpa in the middle. Zacarias is the middle sibling of five, but his two older brothers no longer live at home. One, Pablo, a carpenter, lives in the center of Tlaquilpa with his common-law wife. The other, Evaristo, is working as a bricklayer in Monterrey and comes home only a couple of times a year. So the Aguilar household was inhabited in 2013 by Don Crispin, Doña Felicia, Zacarias (23) and his girlfriend Concepción (19) (who was expecting their firstborn), his younger brother Arón (21) and his girlfriend Petra (21), and the youngest of the siblings, Feliciana (17).

The family plot of land runs on a steep slope covered in pines and oaks, and there is a narrow flat strip at the foot of the ridge where Don Crispin, has his cornfield. It does not produce enough to feed the family throughout the year, but provides a necessary addition to the household budget. Most of Crispin's income comes from carpentry; he has a small wood shop where he makes planks from the trees he can cut down with his chainsaw. He doesn't make charcoal anymore: it is too much work, and the price of the coal is too low these days. Doña Felicia, Zacarias's mother, has a couple of sheep that provide her with wool, which she spins and weaves into thick warm blankets and ponchos for her family. The family is not rich, and, except for the plot of land where they live, which was inherited from Don Crispin's father, what they have comes from their own hard work. Crispin and Felicia married in the late 1980s when Mexico was going through a severe financial crisis, and their life was hard. There were few options for making money, and they struggled to make ends meet. Neither Crispin nor Felicia has any schooling; Felicia learned to read when she was 14, but she doesn't feel comfortable writing. She also doesn't feel comfortable speaking Spanish, and she says she doesn't understand it very well. 
One night, Don Crispin dreamed that a blond man dressed in red came to him and asked in a low friendly voice, "Teh tikneki tiyās Estados Unidos ammo nelle?" [You would like to go to the United States, isn't it true?]. Felix said yes, he would, but the trip was dangerous and expensive. The man replied that no, it wasn't that hard; if he liked, they could go right now. Crispin said yes, and within an instant they were standing in a gigantic fruit field in the United States. As he set to work picking leeks paid a dollar a bundle, he could see that his pay was quickly accumulating as he advanced across the field. He turned to ask the man a question, but he was gone, and the dream was over. Don Crispin never did go to the United States, though several of his cousins and brothers-in-law did. After telling the dream, Don Crispin makes a point of saying that what seems to be the easiest way forward is often simply a lack of imagination. You cannot get everything through magic, but if you focus your mind and invest yourself in working hard, even by farming your own rocky field or selling mutton stew to your neighbors, you may be able to "salir adelante." Sometimes, it is a life choice not to migrate.

Everyone in the household is a Nahuatl- dominant bilingual and all household communication takes place in Nahuatl. Even with me, they only shift to Spanish briefly if they can see that there is something I really don't understand, or if I initiate a conversation in Spanish. The Nahuatl spoken in the household is fast-paced, and playful. When everyone is gathered in the kitchen building, jokes, comments, and questions in Nahuatl fly across the table. The three family members who have the broadest dominion of Spanish speech styles are those who are attending the Intercultural University. Sometimes Arón will shift to Spanish to discuss politics with me. The only members of the household who are addressed mostly in Spanish are the two dogs named Grande and Amarillo.

When the two eldest brothers grew up, there were few options for postsecondary education in the region, the nearest options being in Orizaba and Córdoba several hours away. After finishing primary school, the eldest brother Evaristo had to contribute to the family economy, helping his father in the field. Secondary school was not an option. Pablo started secondary school but didn't finish. Zacarias enjoyed primary school and easily passed on to secondary school. The teachers in his primary school were mostly locals who spoke Nahuatl and were able to use the language as a medium of instruction when students needed it to understand the material. Nahuatl was also one of the topics taught there, and Zacarias remembers fondly the texts from his textbook Nauatlajtoli [Nahuatl language]. This two-volume primary school textbook published by the SEP (Ministry of Education) was written by local teachers specifically for teaching the students to read and write Zongolica variety of Nahuatl, the language most of the students spoke at home. Zacarias was an excellent student, making first in his class several years in a row. In secondary school he quickly mastered Spanish, adding the formal register of the education system to the Nahuatl-influenced vernacular Spanish that he had learned from his friends. His secondary school teacher was also warmly disposed toward the Nahuatl language, even identifying an hour every afternoon in which he required his students to practice their Nahuatl. This was in stark contrast to the secondary schooling experiences of Arón and Ana, both of whom were explicitly prohibited from speaking Nahuatl in their secondary school despite the fact that the Law of Linguistic Rights had been passed several years earlier.

After secondary school Zacharias went to the college preparatory school in a telebachillerato - a kind of rural high school where some of the classes are taught through educational videos, requiring fewer teachers to teach all the topics. But in the telebachillerato in Tlaquilpa the television didn't work, so the two teachers taught all the subjects in person. Zacarias considers that this was to his advantage as the personal contact with teachers made it easier for him to understand the instruction. When Zacarias finished, he knew he would like to keep studying. During the last semester his teachers told him about the Universidad Veracruzana Intercultural (UVI) in Tequila and the Instituto Tecnológico Superior de Zongolica (ITSZ). He chose the UVI both because he was attracted to the sustainability track of its Intercultural 
Development major, but also importantly because tuition was much lower than the ITSZ. Zongolica was also two and a half hours away, which would have required him to rent a room there. Zacarias had received a government scholarship for academic achievement which was enough to cover most of his transportation and tuition costs to the UVI.

The university didn't disappoint him. He quickly grew to enjoy its ambience, the way the teachers taught, and the focus on creating development in one's own community. At the UVI Nahuatl was respected, but not widely used, not even among the Nahuatl -speaking students. During the four years of the program there was only a single semester of Nahuatl, compared to two years of English. Gradually Zacarias gravitated to the health track instead of the sustainability one, especially after he took a course on veterinary medicine. With the skills he learned in this course, he became able to diagnose and treat his family's sheep, chickens, turkeys, and dogs. Eventually he even started practicing veterinary medicine on the weekends, curing his neighbor's animals and making a bit of money for the family. He found that the fact that he spoke Nahuatl was an immense help: because the neighbors felt comfortable with him, they could explain the symptoms and receive the explanations in their own language. Zacarias also taught the basic skills in veterinary medicine to his parents so that they could also make some money through that practice. Drawing directly on the 'salir adelante' discourse, Doña Felicia explains the impact that her boys' education has had on the family, emphasizing the skills in veterinary medicine: "Yi nikixmati tlan pahtle tlan tipo kokólistl para inon kiservirōs ittlān in yölkameh. [...] Pos axān tēserviroa in tlēn yefan omomachtihkeh" [Now I know which medicine works for which kind of illness with the animals. [...] So now what they learned is useful to people.] These are concrete ways in which the skills taught at the UVI, in combination with the use of Nahuatl, has provided the family with new ways to improve their lives.

After graduating, Zacarias found a job at a local development NGO working in the community of Soledad Atzompa, a few hours from Tlaquilpa. Here, he was the only one of the development workers who spoke Nahuatl and found the language useful in creating trust, maintaining the community's engagement and making sure they understood the way the projects worked. Sometimes he felt the fact that he was a licenciado (a person with a college degree), and nonetheless spoke Nahuatl, inspired the people he worked with to think differently of their own possibilities-perhaps seeing that they or their children could also aspire to educational achievement.

His younger brother Arón heard about the UVI from Zacarias, and decided to attend as well. Like Zacarias, he was an excellent student, with a keen and critical mind. His thinking is more political than Zacarias; for him studying at the UVI is not only a way to gain a livelihood, but also part of an ideological stance of indigenous activism. He told me that the UVI awakened this ethnic and social consciousness. At the UVI, his BA thesis was an analysis of the agricultural rituals of the Zongolica Nahuas, in which he analyzed local mythological narratives told in the Nahuatl language, and argued that their implicit cosmovision represented an ideological alternative to the Western paradigm of politics.

The youngest sibling, and only girl, Feliciana, had a different experience from her brothers. She entered primary school speaking only Nahuatl, having almost never heard Spanish at home. Her teachers were locals who spoke Nahuatl to the children, and had the time and patience to explain the exercises to them in their own language. She felt good and safe there. She gradually learned basic Spanish and was able to do her schoolwork, though she never felt she had the talent for it, didn't enjoy it, and consequently preferred to spend her time playing or helping her mother in the house. When she started secondary school all of this changed. In the secondary school, everything was in Spanish, the teachers came from cities like Orizaba and Córdoba, and had a different idea of discipline and educational achievement than her primary school teachers. There, students were expected to be proficient in Spanish, and there was little time or will to provide additional explanation to those who weren't. In this environment Feliciana realized that she spoke a lot less Spanish than her peers, and 
consequently had a harder time doing many of the basic tasks, or even understanding what her teachers were talking about. This of course led her to fall further behind her classmates, which they of course also noticed, making her the butt of cruel jokes and comments. Under these circumstances, it was perhaps unsurprising that she told her mother one day that she was not going to continue studying the next year. Her parents ascribed her choice to lack of responsibility and self-discipline, but accepted it. Now she spends her days with her mother in the house, helping with choresconforming in some ways (at least currently) to the Nahua kinship model of the kalyollotl [the heart of the house]: the girl of the family who never marries but takes care of her aging parents.

\section{Salir Adelante: Language and Development}

Messing (2002, 2007a) describes how the salir adelante discourse emerges in the experiences of elderly Mexicano people who have seen and experienced the massive changes associated with the advancing process of modernity, affecting concrete aspects of their lives from their access to food and everyday amenities, to the ease with which they can travel between centers and peripheries. That is, Messing recognizes that salir adelante is not primarily a discourse that people encounter and which then motivates particular kinds of action or engenders a particular set of values. Rather, the discourse surges from an experience of one's own life as being a struggle to find ways to exist, and from a realization that it is only oneself who can take on this task. This is the form of life (Wittgenstein 1999) which makes the concept of salir adelante meaningful, and which has been the basic reality for indigenous and working-class Mexicans at least since the colonial period. Similarly, while the menosprecio or pro-indigena views of Nahuatl and indigenous identity are indeed discourses or ideologies, they are not only that. They are also life stances that play a crucial role in individual people's strategies for salir adelante. Yet in her analysis, Messing $(2002,2007 \mathrm{a}, 2007 \mathrm{~b})$ focuses on the role of ideologies and discourses, to includethe semiotic process of recursivity, in mediating the linguistic choices of Mexicano people. This focus is warranted in so far as Messing's declared goal is to understand how Tlaxcalan Mexicanos use language to construct categories of difference, which then become operational in local language politics.

Nonetheless, the life stories of the Espinoza and Aguilar family remind us that the ground on which discourses and ideologies live, reproduce and become meaningful, is the social lives of individual people. That is, a given discourse is meaningful not only qua its relation to these macro-discourses, but also because of its usefulness as source of meaning within the lived lives in which it is anchored. The same discourses and ideologies may acquire different meanings for different people, simply because not everyone has the same options available to them.

Some, like Zacarias and Arón, are good in school; others are better at building houses, or farming the land. Many don't even have a choice between the two. For some, such as the marihuaneros of Hueyapan in the 1980s, using their indigenous language as a code of solidarity can be a survival strategy, making it easy to discern between trustworthy locals and suspect outsiders. For others, such as Feliciana, the language is an obstacle for even obtaining a basic education, or simply an irrelevant skill for someone who has chosen to pursue a life far away from the community where it is spoken. Yet others, such as Zacarias, Rodrigo, and Clara, growing up in other circumstances, have the possibility of making their mother tongue or ethnic identity the basis of a life-project, by investing themselves in attending to the needs of their local community (whether as provider of veterinary medicine, or as a missionary), or by using their language skills as social capital in the pursuit of social mobility. The linguistic choices motivated by the salir adelante discourse are different in each of these cases.

In Tlaquilpa, because of the predominance of Nahuatl as a vernacular, scarce resources and the lack of infrastructure, the Spanish language and the access to post- 
secondary education that it facilitates are in high currency. Like Feliciana, many youths experience Nahuatl as an obstacle for achieving their goals and life projects. Many of them never make it through secondary school, not to speak of college preparatory schooling. Others who do make it through college prep are intent on getting a well-paid job that can help their families - this is primarily what the Technological University of Zongolica promises, but does so largely without integrating any attention to the local language and culture in its curriculum. With the establishment of the UVI a new option has appeared in the educational lives of Zongolican youths. It holds the promise of an education where one can use one's mother tongue in the process of improving the living standard of one's own family or even of one's community - even if it is through relatively small improvements like raising the chance of livestock surviving to adulthood, as it was for the Aguilar family. In this way the ITSZ and the UVI offer their students markedly different strategies for salir adelante: the former conceptualizes social mobility also as a move away from the local form of life, whereas the latter offers improvements of the quality of life within it.

In Hueyapan, the language has been historically tied to a negative spiral of poverty and violence that eventually broke the chain of transmission. It is hard to deny that this network of negatively valued indexicalities, as well as the practical circumstances of life that nurtured it, has led to the current situation of advanced language shift there, and in other communities in Morelos. Although, the case of Clara shows that this dynamic may be reversed, when the language itself comes to be experienced as a bedrock of security. Furthermore, with the current economic and political resurgence of Hueyapan, Nahuatl is now in the process of being resignified as a source of positive identity, as something to be proud of and to build on. Some youths, such as Pablo Aguilar or Renato Espinoza, may decide to abandon the language and identity entirely for the values of modernity, for example to make new lives in the United States. But others, such as Clara and Ana Espinoza, are drawn back to the family hearth made attractive by ideologies of communal cohesion, or by government policies to stimulate what they call "development with identity." For Clara the Nahuatl language came to be indexically tied to her earliest experiences of stability, peace, and spirituality associated with her grandmother, in contrast to the violent traumatic experiences that she associated with her father. This highly subjective genealogy of experiences made the peaceful rationalistic community of the Witnesses a perfect setting for her to develop a life project, and the Nahuatl language which enabled her to become a successful witness became an important vehicle for achieving it. Arón, in turn associated the language with a political project of ethnic and class liberation, and the language became both the emblem of the political identity and the means with which to carry out the struggle. In each case we see a recursive process where lived experience motivates a choice of ideology, which in turn motivates a reinterpretation of one's own life as fitting into a specific narrative.

\section{Interpreting One's Life: Language Decisions and Subjectivity}

I wish to conclude by considering the wider ramifications of my argument about the relation between existence and meaning. Life and language stand in a figure-ground relationship to each other, but as in the famous rabbit-duck optical illusions we have a choice about which we see as the figure and which as the ground. When we explain people's life choices as acquiring meaning through discourses and ideologies, we see language as the ground of life. This perspective seems useful when we want to describe social processes at the macro-scale. But I would argue that from the perspective of subjective existence and its languaging activity, life is the ground against which language becomes meaningful. Taking such a perspective enables us to analyze the interaction between social processes and individual agency.

Within the complex tissue of a lived life it is doubtful if we can ever define simple paths of causation between specific life experiences and language attitudes. 
For example, when Ana denies a causal effect between her rejection by CDI and her decision to adopt a more "indigenous" lifestyle, I cannot contradict her view of what causes her actions. But instead of focusing on specific causation, I would suggest that we can see the change as happening as she came to interpret her life in a way that made it seem as if the Nahuatl language was missing from it. This happened in a political context where she was unable to leverage a social capital that her siblings had access to, posing a concrete obstacle for her immediate life project. I think we should be reluctant then, to reduce Ana's choice to simply a form of "forced identity" (Friedlander 1975), or a shallow refashioning of oneself to fit the "indigenous slot" (Karlsson 2003), because she experiences it as an existential choice. In contrast, Feliciana herself describes a causal correlation between being a dominant Nahuatl speaker and her lack of success in the education system. But her parents and brothers contradict this, interpreting it instead as caused by a lack of will to salir adelante. In this way, we see choices, themselves the interpretants of life events and grounded in our experience, becoming signs for others to interpret.

Hence, to understand the value of Nahuatl, and how individuals experience it as being either a boon or an obstacle in their lives, we have to understand not only the explicit social valorization of the language in different discourses and in different contexts but also the role that these valorizations come to play in how Nahua people experience their own lives. In the context of Mexico's current language policy paradigm in which indigenous languages are valorized positively in official discourse, paying attention to the concrete affordances offered by language policy in the lives of speakers and would-be speakers helps us understand the contradictions and paradoxes that unfold as policy translates into practice. Such attention to the policy-practice interface, and to how institutional changes enter the lives of Nahua peoples, allows a critical examination of the effects of language policies. Some scholars for example have critiqued the intercultural universities for placing insufficient focus on indigenous languages and culture (e.g., Olko and Sullivan 2014:391; Sullivan 2011:46), for focusing too much on promoting literacy (Lehmann 2013), or for being too superficial in their engagement with indigenous cultural concerns to be an expression of a genuine intention of educational inclusion by the government (Dimas Huacúz 2006; Llanes Ortiz 2008). But the experiences of the Aguilar family show that in spite of the various shortcomings at the structural and political level, it is possible for Nahua students and their families to benefit from the educational offers of the Intercultural University - and for the university to exercise a positive effect on the social status and vitality of the language. This echoes the optimistic conclusions of Rockwell and Messing (2006), but adds the aspect of showing that obstacles in other aspects of Nahua lives severely circumscribe the efficacy of these policies. Such obstacles include for example the lack of Nahuatl language use in secondary schooling and other basic services, lack of access to work and economic opportunity in Nahuatl -speaking regions, and the relative absence of Nahuatl -speaking role models, social disruptions caused by violence, etc. When Nahua people interpret their lives and proceed to make linguistic choices based on that interpretation, all of these variables factor into the fabric of experience that makes up the indexical ground. By describing what speaking Nahuatl has meant to the members of two families within the specific circumstances of their lived lives, I believe to have shown that in the end, this is the kind of difference language makes.

\section{Notes}

Acknowledgments. This paper was written while I was a fellow at the center for US-Mexican studies, at UCSD. My greatest gratitude is due to the members of the two families that invited me to stay with them and allowed me to write about their lives. I would also like to thank Paja Faudree, Paul Kockelman, for conversations that inspired the article, and Richard Baumann, and Paul Manning for the comments they provided as judges of the SLA graduate student 
essay contest. I also thank Guadalupe Tzopitl for her corrections to my Zongolica Nahuatl abstract. Finally I would like to thank the four anonymous JLA reviewers for their comments that greatly improved the article. Any remaining errors and problems are my own.

1. I have given the families and their members pseudonyms and altered some details of their histories to protect their identities. Both families have consented to my describing them in this paper.

2. The historical political relation between Tetela and Hueyapan is not developed in Friedlander's book which focuses on the relation between Hueyapan and the national government, but it is my distinct impression from my own decade of research that the tense relation between the two communities has been of crucial political significance in Hueyapan. For a summary of this relation, see Pharao Hansen (2015).

\section{References}

Brice Heath, Shirley

1982 What No Bedtime Story Means: Narrative Skills at Home and School. Language in Society 11(1): 49-76.

1972 Telling Tongues: Language Policy in Mexico-Colony to Nation. New York: Teachers College Press.

CDI [Comisión Nacional Para el Desarrollo de los Pueblos Indígenas]

2012 Memoria documental: desarrollo con Identidad para los Pueblos y las comunidades indígenas. 2006-2012 / Comisión Nacional para el Desarrollo de los Pueblos Indígenas. México: CDI

Dimas Huacuz, B.

2006 i Interculturalidad de Papel? Apuntes sobre la idea de universidad indígena. Revista Futuros, México 4(14): 23-29.

Duranti, Alessandro

2006 The Social Ontology of Intentions. Discourse Studies 8(1):31-40.

2009 The Relevance of Husserl's Theory to Language Socialization. Journal of Linguistic Anthropology 19:205-226.

2010 Husserl, intersubjectivity, and anthropology. Anthropological Theory 10:1-20.

Flores Farfán, José Antonio

2011 "Keeping the Fire Alive: A Decade of Language Revitalization in Mexico. International Journal of the Sociology of Language 212:189-209.

1999 Cuatreros somos y toindioma hablamos. Contactos y conflictos entre el náhuatl y el español en el sur de México. México: CIESAS.

Friedlander, Judith

1975 Being Indian in Hueyapan: A Study of Forced Identity in Mexico. New York: St. Martin's.

Hanks, William F.

1990 Referential Practice: Language and Lived Space among the Maya. Chicago: University of Chicago Press.

1992 The Indexical Ground of Deictic Reference. In Rethinking Context, Language as an Interactive Phenomenon. A. Duranti and C. Goodwin, eds. Pp. 43-77. New York: Cambridge University Press.

1996 Language and Communicative Practices. Boulder, CO: Westview.

Hill, Jane H., and Kenneth C. Hill

1986 Speaking Mexicano. Dynamics of Syncretic Language in Central Mexico. Tucson: The University of Arizona Press.

INALI [Instituto Nacional de Lenguas Indigenas]

2012 Informe y Rendicion de Cuentas 2006-2012. Mexico: INALI.

INEGI [Instituto Nacional de Estadísticas, Geografia e Informática]

2005 Perfil sociodemográfica de la populación hablante de náhuatl. XII Censo General de Población y Vivienda 2000 (Publicación única ed.). Aguascalientes, Mexico: INEGI.

Karlsson, Bengt G.

2003 Anthropology and the 'Indigenous Slot' Claims to and Debates about Indigenous Peoples' Status in India. Critique of Anthropology 23(4):403-423.

Kockelman, Paul

2013 Agent, Person, Subject, Self: A Theory of Ontology, Interaction, and Infrastructure. New York: Oxford University Press. 
Lehmann, David

2013 Intercultural Universities in Mexico: Identity and Inclusion. Journal of Latin American Studies 45(4):779-811.

Llanes Ortiz, Genner de Jesús

2008 Interculturalización fallida: Desarrollismo, neoindigenismo y universidad intercultural en Yucatán, México. TRACE 53:49-63.

Messing, Jacqueline

2002 Fractal Recursivity in Ideologies of Language, Identity and Modernity in Tlaxcala, Mexico. In Proceedings of the Tenth Annual Symposium about Language and SocietyAustin. Texas Linguistic Forum 45: 95-105.

2007a Ideologies of Public and Private Usages of Language in Tlaxcala, Mexico. International Journal of the Sociology of Language 187(188):211-227.

2007b Multiple Ideologies, Competing Discourses and Language Shift in Tlaxcala, Mexico. Language in Society 36(4):555-577.

Messing, Jacqueline, and Elsie Rockwell

2006 Local Language Promoters and New Discursive Spaces: Mexicano In and Out of Schools in Tlaxcala In Mexican Indigenous Languages at the Dawn of Twenty-First Century. Margarita Hidalgo, ed. Pp. 249-279. New York: Mouton de Gruyter.

Olko, Justyna, and John Sullivan

2014 Toward a Comprehensive Model for Nahuatl Language Research and Revitalization. Annual Meeting of the Berkeley Linguistics Society 40: 369-397.

Ochs, Elinor

2012 Experiencing Language. Anthropological Theory 12(2): 142-160.

Pérez Báez, Gabriela

2014 Determinants of Language Reproduction and Shift in a Transnational Community. International Journal of the Sociology of Language 27: 65-81.

2012 The Unexpected Role of Schooling and Bilingualism in Language Maintenance within the San Lucas Quiaviní Zapotec Community in Los Angeles. Anthropological Linguistics 54(4): 350-370.

Pharao Hansen, Magnus

2010 Nahuatl among Jehovah's Witnesses in Hueyapan. International Journal of the Sociology of Language 203:124-137.

2015 The Role of Community Politics in Language Revitalization: The Case of Hueyapan. Paper presented at the second conference for Mesoamerican Linguistics, California State University, Los Angeles, March 6.

Rindstedt, Camilla, and Karin Aronsson

2002. Growing Up Monolingual in a Bilingual Community: The Quichua Revitalization Paradox. Language in Society 31(5): 721-742

Schmelkes, Sylvia

2000 Education and Indian Peoples in Mexico: An Example of Policy Failure. In Unequal Schools, Unequal Chances Challenges to Equal Opportunity in the Americas. F. Reimers, ed. Pp. 319-333. Cambridge, MA: Harvard University Press.

2009 Intercultural Universities in Mexico: Progress and Difficulties. Intercultural Education 201: 5-17.

Silverstein, Michael

2003 Indexical Orders and the Dialectics of Sociolinguistic Life. Language \& Communication 23:193-229.

1996 Monoglot 'Standard' in America: Standardization and Metaphors of Linguistic Hegemony. In The Matrix of Language: Contemporary Linguistic Anthropology. Donald Lawrence Brenneis and Ronald K. S. MacAulay eds. Boulder, CO: Westview.

Sullivan, John

2011 The IDIEZ Project: A Model for Indigenous Language Revitalization in Higher Education. Collaborative Anthropologies 4(1):139-154.

Wittgenstein, Ludwig

1984 Culture and Value. G. H. von Wright, ed. Peter Winch, trans. Oxford: Blackwell. 1999[1958] Philosophical Investigations. 2nd edition. Oxford: Blackwell Publishers.

Zentella, Ana Celia

1997 Growing Up Bilingual: Puerto Rican Children in New York. Oxford: Blackwell.

2005 Building on Strength: Language and Literacy in Latino Families and Communities. New York: Teachers College Press. 